ized analysis, its limitations and its method of approach. Chapters 2 and 3 , entitlod, respoctivoly, "The Fundamontal Machine" and "Two-Axis Theory", comprise the setting up of the machine equations in terms of the basic two-phase systom and the devolopmont of the transformations for two-axis representation. In these two chapters, in the course of developing and manipulating the equations, the notation of matriees and cortain matrix operations aro introduced.

The next two chapters deal with transient and subtransient conditions and with tho sotting up of tho torque equations and, in the latter connexion, the rules of matrix multiplication ore more fully exemplified. It is at this point that tho analysis of machinos of different types is taken up, direct current machines, induction motors and gonoral commutator mashinos forming the subjocts of individual chapters. The treatment is completed by a chapter dealing with small oscillations.

'Tho book concludes with a short chapter entitlod "Tensors" in which the author doscribos tho relationship of olectrical machine theory to differential geometry, the absoluto differontial calculus and to tonsor calculus.

No prior knowledge of matrix theory is assumed. The requisite rules of operation are doveloped as requirod and their utility and validity demonstrated by appropriato examples. The most important fundamental concept of tho "connoction matrix" is introducod in tho simplo example of tho d.c. sorios machino and is then more fully developed in relation to a.c. machines. The author statos at tho outset that, "The true concepts behind the two-axis theory are mathomatical and for that reason the mathomatical treatment in this book is less cornplicated and more satisfying than tho usual physical approach". This claim can, in large measure, be sustained. The thoory is dovoloped in a eloar, logical and systomatic fashion and constitutes an oxcollent introduction to the subject. Nono the less, physical conditions viewed along with mathomatical dovolopmont can illuminato the subject and, by adding realism, carry conviction. Tho basic concopts which undorlie two-axis theory could with advan tago have been illustratod from tho physical point of viow.

Dr. Gibbs has arranged his presentation of tho subject so as to load into tho important topies with a minimum of digrossion, and he has succooded in doveloping with remarkable economy and clarity the principles of the subject to a point at which the reader can enter the more goneral literature of tho ficld. To a reador with i bookground knowledge of the conventional theory of electrical machines the troatmont is admirably suited. In particular the book will serve woll the needs of teachers of undergraduato courses dealing with electrical machines, and of students in the final yoar of such eoursos. J. GREIC

\section{A RUSSIAN VIEW OF EARTH HISTORY}

Basic Problems in Geotectonics

By V. V. Beloussov. Edited by John C. Maxwell. 'Iranslatied by Paul T. Broncer. (International Sories in thes Earth Sciences.) P'p. xvi +809 . (New York: McGrawHill Book Company, Inc.; London: Me(traw-Hill Publishing Company, Ltd., 1962.) 108s. 6d.

$B$

ASIC Problems in Geotectonics is a monumental synthesis of Earth structure in which Dr. Beloussov presents what he believes to be the main outcome of geotectonic research in the U.S.S.R. since the Revolution. The subject has long been a controversial one, and som(s of the facts and theories presented in this book aro likely to be disputod by many workors in this field.

After a preliminary summary of tho history of develop ment of gootectonics there follow an outline of the intornal structure of the Earth and a discussion of its origin. The classification of structural forms observed in rocks exposed at the surface is both novel and stimulating. Tho following section on present and past vortical oscillatory movements is an important ono, as these observations form the basis of his main thesis. The maps and sections which illustrate the variations in facies and thicknesses of Palrozoic and Mesozoic formations in Central and Western Russia should prove to be of par. ticular interest to workers outside the U.S.S.R., as they give a clear summary of dotailed work not always easily accessible in this form. The next section discusses the theories of formation of folds and faults, and tho last two parts present Dr. Beloussov's viows on the processes which have led to the arrangement of the larger structural units.

Dr. Beloussov is very critical of tho idea that orogonic belts are developed in regions of large horizontal displacement, although he does find it difficult to see how vertical movements alone can lead to the development of mountain chains where the rocks havo beon tightly folded and apparently strongly compressed. His belief in the prime importance of vertical movements loads him to assume that our knowledgo of linear fold zones is totally in. adoquate and probably fundamentally incorrect. $\mathrm{H}_{0}$ suggests that the folding in the Appalachian Mountain chain has been incorrectly interpreted, and that the grenter part of the nappo structure of the European Alpine chain is geometric speculation and, to uso one of his favourite and frequent criticisms, "formalistically unsound". Tho notion that all fold belts are developed on the plan of the Alpine model could cortainly be criticized, but Dr. Boloussov's denial of the accepted structural geometry of the Alps seems scientifically irresponsible. For example, no Alpino goologist would dispute that the Prealpino nappes have been displaced horizontally at least $60 \mathrm{~km}$, not, as Beloussov suggests, a mere $11 \mathrm{~km}$. He explains the formation of lincar fold belts by vortical movemonts on long and doep funda. montal flaws in the crust. Vertical movements on these faults lead to the stretching of tho sedimentary cover, and a later reversed movement of the fault-block causes the provionsly stretched beds to become shortened and folded as they settle back into their original position.

Dr. Boloussov believes that the deep ocean basins reprosent regions of subsidence formed as the result of a process of basification or "basaltization" of a relatively homogeneous granitic crust in comparatively recent geological timo.

This is a book which all interested in Earth structure should read, for in it the ovidenco supporting the theory of oscillatory vertical movements of the crust is fairly fully documented. It should stimulate the reador to re-examine many of the generally accepted facts and theories, although Dr. Beloussov's partisan approach to Earth science might be found to be somewhat exasperating.

J. G. RAMsay

\section{THE HALLEY BAY EXPEDITION OF THE ROYAL SOCIETY}

\section{The Royal Society International Geophysical Year} Antarctic Expedition

Halley Bay, Coats Land, Falkland Islands Depondencies, 1955-59. General Editor: Sir David Brunt. Vol. 2: Radio Astronomy; Ionospheric Physics. Pp. xv $+289+14$ plates. Vol. 3: Seismology; Meteorology. Yp. xvii + $382+5$ platos. (London: The Royal Society, 1962.) $140 s$, 23 dollars por volumo.

R IGHT from the inception of its Intornational Geophysienl Yoar Antarctic Expodition it has been one of the aims of the Royal Society that the results should be available promptly, particularly in view of the pace of 